\title{
When memory becomes heritage: Experiences from Santiago, Chile ${ }^{1}$
}

\author{
Maria Chiara Bianchini \\ Instituto de Historia, Universidad Católica de Chile, Campus San Joaquín \\ Avda.Vicuña Mackenna 4860, Macul, Santiago \\ e-mail: mbianchini@uc.cl
}

Submitted: 14 September 2014; Accepted: 31 October 2014

\begin{abstract}
This article explores the relationships between memory politics and urban heritage in the construction of a twenty-first century democratic society. It focuses on the case of Chile and concentrates on three examples of public buildings in the capital city, Santiago. Given what can be considered a difficult heritage -linked to the recent experience of dictatorship and state sponsored violence- these buildings have been in recent years objects of heritage politics, directed to address a public memory related to those events. Based on these case studies, the article critically discusses the materialization of the dominant human rights discourse in the current memory politics affecting Santiago's urban heritage.
\end{abstract}

KEYWORDS: Chile; military dictatorship; transition to democracy; memory politics; urban heritage; monuments; memorials; human rights

Citation / Cómo citar este artículo: Bianchini, Maria Chiara (2014). "When memory becomes heritage: Experiences from Santiago, Chile”. Culture \& History Digital Journal, 3(2): e023. doi: http://dx.doi.org/10.3989/chdj.2014.023

RESUMEN: Cuando la memoria se convierte en patrimonio: algunas experiencias desde Santiago de Chile.- Este artículo aborda las relaciones entre políticas de memoria y patrimonio urbano en el proceso de construcción de una sociedad democrática del siglo XXI. El análisis se centra en el caso de Chile y presenta tres ejemplos de edificios públicos de la capital, Santiago. Los tres sitios representan lo que puede considerarse un patrimonio difícil-vinculado a una reciente experiencia de dictadura y violencia de Estado- y, por esta razón, han sido objeto, en años recientes, de políticas patrimoniales dirigidas a gestionar la memoria pública de esos eventos. A través de estos casos, el artículo analiza críticamente la materialización del discurso dominante de los derechos humanos en las actuales políticas de memoria que afectan al patrimonio urbano de Santiago.

PALABRAS CLAVE: Chile; dictadura militar; transición a la democracia; políticas de la memoria; patrimonio urbano; monumentos; memoriales; derechos humanos

Copyright: ( 12014 CSIC This is an open-access article distributed under the terms of the Creative Commons AttributionNon Commercial (by-nc) Spain 3.0 License.

\section{INTRODUCTION}

Contemporary memory culture is characterized by the existence of a human rights paradigm that throughout the last decades has become a hegemonic framework for the interpretation of the atrocities of the twentieth century. Referring to memory processes in Latin-America, Argentine scholar Elizabeth Jelin points out that, while political conflicts and repressive processes were understood nor- mally as a matter of "winners" and "losers", from the seventies onwards, the human rights paradigm implied that the crimes of the military dictatorships gradually started to be recognized as "human rights violations". In this framework, these crimes became the object of local as well as international struggles and, later on, the subject of initiatives related to memory politics and transnational justice (Jelin, 2013). While recognizing that the installation of such a paradigm in contemporary culture has per- 
mitted important progress in the public condemnation of violent regimes and the provision of reparations to victims around the globe, in recent years some scholars have pointed at the deficiencies and dangers of adopting this discourse and only this discourse to understand and deal with specific conflicts and violent processes. ${ }^{2}$ One of the key points of this approach, which is also relevant in the field of heritage studies, is to critically rethink the widely accepted, and to some extent normative, principles that assume a direct connection between the public memorialization of past violence through a human rights-centered discourse and the construction of democratic societies and new cultural identities that are able to prevent the repetition of such crimes.

The aim of this article is to contribute to this debate focusing on the case of Chile. I will begin by reflecting on the politics of memory that target the last military dictatorship (1973-1990). The repressive practices carried out by the Chilean State during this period have been classified as genocide, since they were part of a broader plan directed to eliminate a certain part of national society. ${ }^{3}$ The military dictatorship's re-foundation project called for the eradication of a whole group of Chilean citizens, as well as non-Chileans residing in the country. Not only their physical bodies were made to disappear, but also their ideas, their symbolic references and their ways of living and thinking also had to disappear. These violent events took place with the consent and indifference of a large part of Chilean society, and, hence, their political and historical meaning has been a difficult and conflictive topic. Yet, the memory politics and practices related to this dictatorial violence have been a fundamental aspect of the transition to democracy, which formally began in 1990 .

In the second decade of the $21^{\text {st }}$ Century, Chile is considered to be a consolidated democracy that has left behind the conflicts that past violence largely projected over the national community. Moreover, Chile's experience in the management of its difficult recent past is regarded as an example of how a democratic country can overcome a violent past by utilizing a public discourse framework that centers on the concepts of memory and human rights. In this sense, the Chilean experience has become a model for activists who are engaged in memory issues in other geographical contexts, as it is taken as a reference to design the politics of memory concerned with traumatic pasts elsewhere. For example, the reference to Chile seems particularly relevant in civil society and even institutional initiatives regarding the memorialization of Francoist repression in Spain. ${ }^{4}$ Given that the Chilean case is being taken as an international reference in the field of memory politics, this paper offers a critical analysis of the processes through which the memory and human rights discourse concretely materializes in $21^{\text {st }}$-century Chile. My intention is to put into evidence the complexity of implementing this discourse in the conflictive Chilean memory-scape. To do so, I will concentrate on how the politics of memory that regulate Santiago's urban heritage try to contribute to the process of overcoming a difficult and di- visive dictatorial past through a public discourse that responds both to the human rights paradigm and to the need to build basic forms of consent in a post-conflict national community.

The article will focus on the material traces of the dictatorship's recent past in Santiago and the ways in which some urban objects that were considered to be "difficult", "dissonant" or "negative" forms of heritage have now become part of National Heritage (see Ashworth and Tunbridge, 1996; Logan and Reeves, 2009; MacDonald, 2009; Ortiz, 2013). To do so, I will refer to the original concept of lieux de mémoire conceived by Pierre Nora (1984), which considers the symbolic and material objects that materialize memories with reference to the Nation and National History and how in doing so these objects actually incarnate various layers of meaning related to the long-term horizons of the Nation. I will invoke Riegl's definition of historical monument as an object "whose historical value lies in the fact that it represents a specific period, that is somehow unique [...]" (Riegl, 1987 [1903]: 57). That is, historical monuments are not expressly built to commemorate something, but they are pre-existing objects that acquire a value as heritage in specific cultural circumstances because they represent a certain event or historical period, whose material traces are considered worth conserving. In this perspective, I focus on urban, architectural objects that the Chilean State considers and manages as historical monuments and that materialize the inclusion of the recent dictatorial past into the realm of National Heritage. They are public and institutional sites and therefore specifically significant and reserved for state-exercised memory politics. However in the process of constructing a democratic national society, at the same time, this heritage displays the dynamics of different memories and identities that participate in the construction of what is considered to be "historical" and "public".

As Francois Hartog has stated, "heritage is the most tangible and visible alter-ego of memory" (Hartog, 2007: $25)$. Heritage is not an ever-increasing number of objects from the past that we have to preserve due to their intrinsic historical value, but a cultural and political construction made of selected elements that is always in a process of change. There are as many heritages as there are actors who define and transmit them. This article takes note of three examples of architectural heritage that are considered to be representative of the Chilean nation: the House of Government, the National Stadium and the $G a$ briela Mistral Cultural Center. They are emblematic buildings that represent the state and its institutions, and, in recent years, they have been the objects of heritage politics that use their symbolic meaning as evidence of past state violence. From their own specific perspective -which simultaneously can be labeled as architectonic, urban, performative and political- each of these three buildings narratively demonstrates the process by which the dictatorial past and its crimes have become part of a national heritage that defines itself as democratic through a framework of public discourse that centers on a human rights approach to recent violence. 


\section{HERITAGE AND THE BATTLE OF MEMORY}

Ten years ago, Chile was defined as a "divided" country because of its recent past (Huneeus, 2003). In 1973, many Chileans wished for and supported a military intervention. They believed that it was necessary for the military to take over Salvador Allende's socialist government in order to reestablish traditional order and democracy. After the 1988 referendum that marked an end to the military regime, electoral results showed that almost half of Chileans continued to support Pinochet. ${ }^{5}$ In 1990, the dictator handed over the government to the first elected president, proclaiming his satisfaction for what he -and his supporters- considered an "accomplished mission": he had taken over the direction of a country that was mired in political and economic disaster, and he was now handing over a country that was pacific, productive and on the path towards democracy. ${ }^{6}$ This "memory of salvation", as Steve Stern has defined it $(2004,2006)$, was the hegemonic interpretation of recent events through which the dictatorship built its legitimacy and exercised overt forms of censorship and repression. For many Chileans, this idea of salvation continued to explain the cause and, indeed, the justification for the military regime. For them, Pinochet's decline as a public figure was more influenced by scandals related to the financial crimes he committed, which started to come to light in 2005 , than by the progressive public acknowledgment of the systematic abuses perpetrated by its government. The magnitude of those crimes was something that many Chileans wanted not to see. ${ }^{7}$ For many, these crimes were considered to be isolated excesses that were the "collateral effects" of the dictatorship's salvation mission, a mission that existed in a context that was perceived as an internal war.

The installation of the military dictatorship was carried out through the deployment of a repressive apparatus that between 1973 and 1977 produced hundreds of deaths and disappearances and thousands of political detentions and acts of torture. At the same time, hundreds of thousands of Chileans were persecuted, expelled from their jobs and forced into exile. These policies were a substantial part of the dictatorship's declared project to "start a new phase in the nation's destiny", which implied the necessity to "change the mentality of Chileans". ${ }^{8}$ The visibility of these crimes was used as a strategy for social control. However, they were also systematically covered up by the media and denied by the institutions. The prolonged negation of the existence of such crimes has been one of the most terrifying aspects of the violence perpetrated by the state against a segment of its own citizenry -the most important example being the practice of forced disappearance: hiding and destroying the bodies of those killed.

Since the late seventies, these events have been the object of what is often referred to as memory battles (Illanes, 2002; Stern, 2006; Winn et.al., 2014), a struggle induced by the regime's victims and opponents in an attempt to publicly denounce the regime's illegitimacy and criminal nature. The struggle for truth and justice regarding killings, disappearances and, in more recent years, regarding the military government's use of torture and other kinds of abuses, has undergone distinct phases. Some of the key turning points in this process include: the massive protests in the 1980s, which brought together people who sought to overthrow the regime; the electoral victory of the 1988 referendum; the beginning of electoral democracy in March of 1990, which marked the end of the regime but also safeguarded Pinochet's position as the military Commander-inChief until 1998; the 1990 publication of the Rettig Report, which established an official, although limited, acknowledged truth regarding the assassination and disappearance of more than three thousand persons (Comisión Nacional de Verdad y Reconciliación, 1996 [1991]); the international trial against Pinochet, which provoked an "irruption of memory" (Wilde, 1999) that started in October 1998 and that had important political, judicial and cultural consequences in the country; and finally, the publication of a second report in 2004 on nearly forty thousand cases of people who had been imprisoned and tortured (Comisión Nacional sobre Prision Política y Tortura, 2004).

Although the memory battles have been part of a difficult and nonlinear process, thanks to the persistence of hundreds of people and organizations involved in this struggle, and to internal and external events as mentioned above, the battle of memory has been won in the twentyfirst century. The Chilean state has recognized and continues to recognize the genocidal practices of the military regime. There still are important deficiencies -as well as juridical and political obstacles- in the implementation of justice and the attribution of responsibilities. ${ }^{9}$ However, denying the human rights abuses committed between 1973 and 1990 is no longer acceptable in Chile's public sphere. The reasons for this are multiple; however, this outlook towards Chile's recent past is largely due to the continuity of the governments that have led the transition process, which were all formed by a coalition called the Concertación (Agreement), born from the NO Campaign that defeated Pinochet in the 1988 Referendum and that was based on an alliance between the Christian Democrat Party and the Socialist Party. The Concertación coalition included many political leaders that were closely connected to victims or had themselves been victims of the dictatorship's crimes. This was especially the case during its two socialist governments - presided by Ricardo Lagos (2000-2006) and Michelle Bachelet (2006-2010). The Concertación coalition established a path of memory politics that managed recent state violence in the framework of a human rights based discourse, although the materializations of such discourse in concrete public gestures and measures have been highly determined by the realpolitik of the democratic transition and the need to promote social peace and reconciliation. More recently, the human rights discourse also guided the memory politics of the right-wing government that ruled between 2010 and 2014 , and that was based on a political coalition that included the Unión Demócrata Independiente, a political party linked to Pinochetism. Some of the public gestures carried out by this government during the commemora- 
tion of the $40^{\text {th }}$ anniversary of the military coup in 2013 demonstrate that, in $21^{\text {st }}$-Century Chile, a public discourse that focuses on the public condemnation of human rights abuses has become the hegemonic framework in the public references towards and interpretations of the dictatorial period. ${ }^{10}$

Santiago's urban heritage illustrates the process by which public memory discourses have been transformed in many ways. The 1973 coup was practically simultaneous to the complete occupation of public spaces in the capital city. The military took control over Santiago in the first days of the coup. They occupied public buildings and universities, and they imposed a strict curfew that lasted many years and that practically eliminated nightlife in the city. Besides that, the names of some streets and buildings were immediately changed and mural paintings and plaques were removed (Errazuriz, 2009). Later on, new monuments were built, the most notorious example being the Altar de la Patria (Altar of the Homeland), built in front of La Moneda (presidential palace) to commemorate both the Chilean libertador Bernardo O'Higgins and the military forces that participated in the pronouncement of $1973 .^{11}$

Furthermore, during the institutionalization of the military regime that began in 1976-1977, the very concept of "National Heritage" was more strongly addressed by institutional actors than it had been in the past. While this phenomenon can be considered to be an expression of a more general "patrimonial fever", a characteristic of contemporary society (Nora 1992), at the same time, the heritage policies implemented by Pinochet's government were part of his broader national re-foundation project, which not only aimed to write the future of national history, but also re-write its past. In this context, from the late seventies onwards, many buildings in Santiago were declared historical monuments, and some of them were restored during important public works campaigns. Some of these monuments include the colonial buildings that surround the Plaza de Armas; the most emblematic public constructions of the second half of the nineteenth century, such as the Municipal Theatre or the former House of the Congress of Deputies; and, public works built during the Centennial of Independence in 1910, such as the National Library or the Museum of Fine Arts. These are some of the most well known examples of what Pinochet's government considered, promoted and restored as National Heritage. Public works projects completed during the 1930s or later were not included in this list. The constructions built during Allende's government were occupied, and any symbol referring to the former socialist government was eliminated. For example, some bathing facilities for workers were converted into concentration camps, while certain state-sponsored housing complexes built during Allende's government were occupied and allocated to the families of low-level soldiers (Lawner, 2008).

In the twenty-first century, the cultural changes produced by memory battles have again affected urban heritage in the city of Santiago. On one hand, some of the monuments built by Pinochet have undergone new trans- formations, such as the Altar de la Patria in 2005. In addition, some streets have been re-named, like the Avenue named after September $11^{\text {th }}$ (Avenida 11 de Septiembre) whose original name, Avenida Nueva Providencia, was restored in 2013. At the same time, official monuments and inscriptions have appeared in public spaces to commemorate Allende and the victims of the dictatorship. Nevertheless, the changes in public memory have also produced a shift in the official concept of National Heritage. Again, these transformations can be considered part of a broader phenomenon, since during the last two decades the protocols and institutions dedicated to national heritage in Chile have gone through their own process of change, in which the typology and definition of patrimony has expanded. However, from the point of view of memory politics, the recent inclusion of a specific universe of objects pertaining to the recent past categorized as "Memory and Human Rights" in the official definitions of National Heritage is particularly relevant. ${ }^{12}$

During the last decade, many places in the capital city that were once used as sites for detention and torture, or for illegal inhumations, have been declared "historical monuments" under this new category of National Heritage. These historical monuments include the former clandestine detention centers at Villa Grimaldi, Londres 38, José Domingo Cañas and Nido 20, which were declared monuments between 2002 and 2006; the semi-legal exdetention center named 3 y 4 Alamos, that was declared a monument in 2012; the Patio 29 at the General Cemetery used for the inhumation of victims, which was recognized as a historical monument in 2006; the National Stadium and the now-called Victor Jara Stadium, that during the dictatorship were used as "prisoners' camps" and which were declared monuments in 2003 and 2009. ${ }^{13}$ Most of these heritagization initiatives have been promoted by civil society associations with strong links to the victims that had direct links to these specific sites. And in most cases, their demands have focused on the protection of these sites from being destroyed or sold. Some of these places have been converted into memorials, which are managed directly by the associations that promoted their "recuperation". This new type of "memory and human rights" heritage has been, in the last years, the object of vast academic production, dedicated to the histories and the specific features of these memorials, including the processes of their "recuperation", the actors involved in these processes and the visual languages adopted in order to transform them into memorial sites (Jelin and Langland, 2003; Collins and Hite, 2009; Lopez, 2009; Violi, 2001; Piper and Hevia, 2012; Aguilera, 2013).

Some scholars place into evidence the efforts and creativity that many of these associations exercise as they connect their memorial work with political activism related to current public issues (Violi, 2011). Yet, many underline the existence of a type of "fragmented" urban memory and note that these kind of places constitute an archipelago of dispersed sites that are strongly marked by the identity of each association that manages them or that are devoted to a specific type of visitor and therefore are 
isolated from general public spaces and debate (Collins and Hite, 2009; Lopez, 2009; Aguilera, 2013). Given this perspective, it could be significant that, even if the great majority of the detention centers in Santiago (legal and illegal), functioned inside military and police precincts, none of them have been converted into memorials, nor have they been the object of other kinds of interventions to commemorate those events. That is, the "heritage of memory and human rights" category is something that does not seem to affect military institutions. At the same time, the existence of memory sites related to the dictatorship's victims does not prevent the installation of other memorials in public spaces that positively commemorate the dictatorship. A prominent example is the memorial dedicated to Jaime Guzmán, one of the main political actors in Pinochet's regime. The memorial was inaugurated in 2008, during the presidency of Michelle Bachelet, in an upper class neighborhood of Santiago, and state authorities oversaw the event. As Aguilera suggests, there even seems to exist a socio-economic difference in the urban distribution of the "Memory and Human Rights" monuments, since none of the sites identified as such are located in traditional upper class neighborhoods (Aguilera, 2013).

In this context, the heritage identified as being related to "memory and human rights" coexists with what is normally considered National Heritage, while barely interfering with it. So, on one side national history is read as a "bright common past", in which memory is something that "that unifies us", a concept reflected in the title of a recent exhibition regarding the history of the National Library. On the other, the uncomfortable past remains enclosed in its own specific places and is devoted to a spe- cific audience. Considering the existence of such apparent contradictions between these two spheres, the cases that I will analyze in the following paragraphs reveal three different experiences of how this contradiction has been addressed in institutional public buildings that not only serve to represent the recent past of state violence, but also national history in a broader sense. These places belong to the state, and they are completely subject to the control of governments and institutions. Consequently, they are especially representative of their memory politics. Nevertheless, since they are public spaces, they have also served as an arena for the confrontation between different institutional and non-institutional actors. These cases demonstrate how, in the $21^{\text {st }}$-century, the Chilean state has transformed a difficult heritage into a national one, inserting human rights discourse into a public memory that aims to represent all Chileans.

\section{THE INVENTION OF TRADITION}

The first example is La Moneda Palace, the traditional House of Government (Fig. 1). Besides being the most renowned historical monument of national heritage, declared as such in 1951, La Moneda is also the physical site of one of the most emblematic scenes of the 1973 military coup. On September $11^{\text {th }}$ of that year, the building was bombed by the Chilean Air Force, leaving parts of it on fire and its ceiling collapsed. This powerful and terrifying image put into evidence the military's radical will. The military destroyed the most prominent symbol of the state, with the clear intention of eliminating those people who were inside, first and foremost the president of the Republic. Pinochet justified the destruction of $L a$

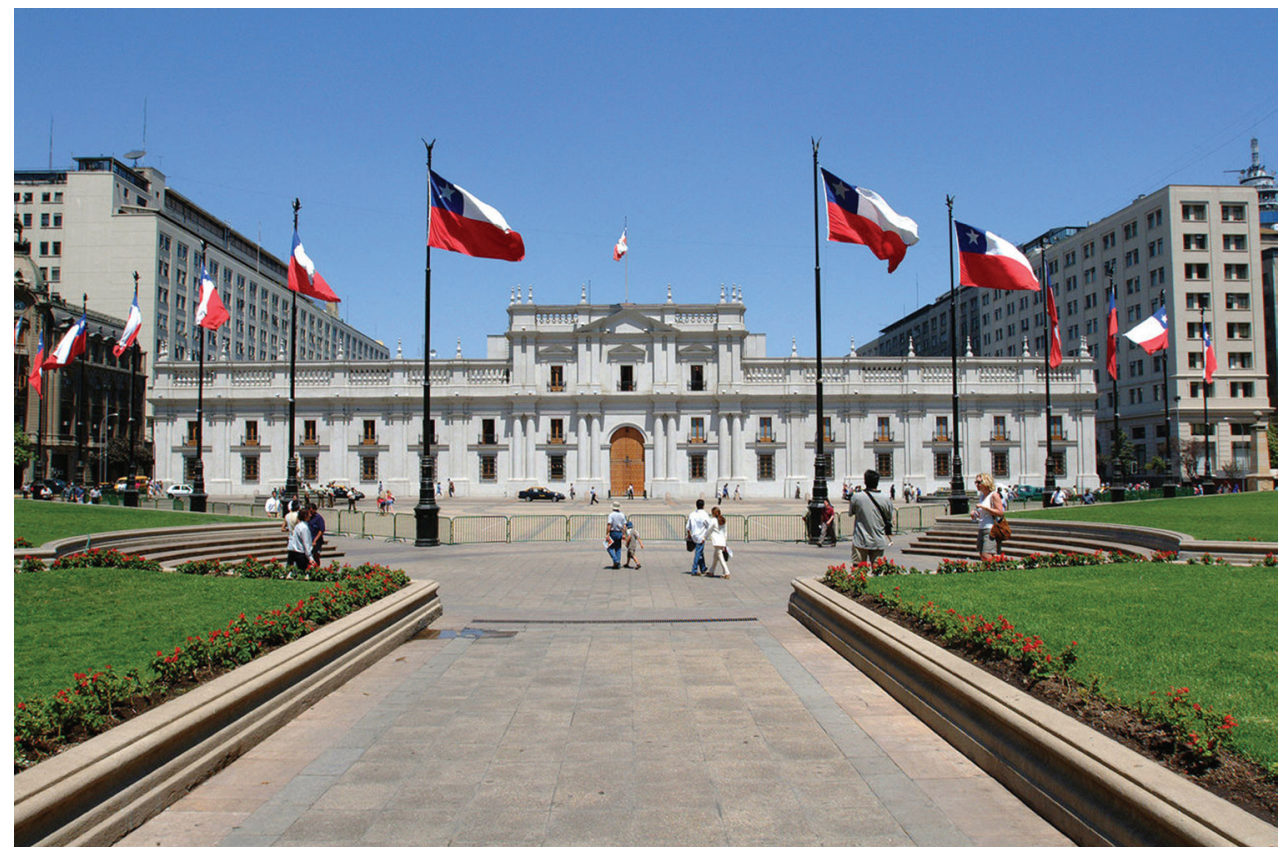

Figure 1: La Moneda palace, viewed from Plaza de la Constitución (2012). Author: Ministerio Secretaría General de Gobierno. Source: Wikimedia Commons [CC-BY-2.0] 
Moneda with his "memory of salvation" discourse, and in this context its restoration became the "symbol of the reconstruction of the homeland". ${ }^{14}$ The restoration of the building began in the late 1970s and was carried at the same time that the military regime began to institutionalize its own project of democratic transition: in 1980 Chileans voted -without any electoral guarantees- on a new Constitution, and in 1981 Pinochet became a "constitutional" president and reinstalled the House of Government in its traditional palace.

When the restoration of the building was concluded, the Ministry of Education published a book about its history and architecture. The book explains that the transformations implemented during the reconstruction responded to the desire of recovering, as much as possible, the building's original concept as designed by the architect Joaquin Toesca in the later years of the Colonial period (ca. 1800). To do so, the building had to be "purified" from the "serious structural damages" that had been produced by the reforms carried out during the twentieth century (Dirección de Archivos Bibliotecas y Museos [DIBAM], 1983: 59). The concept of "national heritage" that was implemented during the building's restoration was based on an interpretation of history in which the 1973 bombing -the "fire" as it is called in the book- was, in fact, an opportunity. Following this principle, the restoration included important changes that drastically modified its internal structure (Bianchini, 2012). Among other things, it implied the disappearance of specific sites, including the presidential office, the "Hall of Independence", where Allende's body was found after his death, and the Morandé 80 door $^{15}$ that was used when the president's remains were removed from the palace and the site where many of Allende's collaborators were detained and kidnapped. These sites and the new structure would acquire symbolic meanings in the ensuing battles of memory.

In 1990, Pinochet handed over the palace to the first elected president, but in the tense climate of the Chilean transition, La Moneda remained untouched and untouchable for ten years. During this phase, the Chilean state rehearsed a style of expressive politics that has been defined as the "engineering of reconciliation", which is to say, the management of a difficult past through negotiation and the search for basic forms of consensus (Wilde, 1999). Some of the most relevant examples of the politics of "engineering" were related to the public treatment of the figure of Salvador Allende. His public funeral, in September 1990, was a private/public event in which every detail was intended to moderate the polemics that it had generated. The same approach determined the history of the statue of Allende that was inaugurated in 2000, in the square in front of La Moneda and that required ten years of negotiations between left and right wing deputies and senators (Hite, 2003).

The Morandé 80 door -which was no longer a door but a plain wall- became a symbol during the first years of Chile's transition to democracy, thanks to episodic tributes that were organized there by the Allende family and the Socialist Party ${ }^{16}$ and to the commemorative dem- onstrations that occurred on September $11^{\text {th }}$, which always tried to pass by this place. For those involved in these acts of commemoration, the erasure of the door became a physical trace of the oblivion that the dictatorship had imposed regarding its crimes and Allende's sacrifice. Nevertheless, the "reconciliation" approach did not allow a space for this kind of memory (and these kinds of memorials) at La Moneda, which was the building that more than any other structure aimed to represent the whole nation. That is why the September $11^{\text {th }}$ demonstrations were never authorized to pass along Morandé Street. Moreover, in 1994, the mayor of the city of Santiago was forced to renounce from public office because of the polemic disputes that arose in reaction to his attempts to authorize demonstrations at this site (Bianchini, 2012: 231).

In 2000, Chile's "reconciliation" discourse began to change under presidency of Ricardo Lagos who arrived at La Moneda at the same time when Pinochet was returning to Chile after being processed in London for crimes related to genocide. Lagos, being the first socialist president of the governing coalition, immediately revealed his intention to renew the symbolic space of La Moneda, as if performing the beginning of a new phase in Chile's transition to democracy. Just before he assumed the presidency, the external walls of La Moneda were restored, and on his first day as president, the main entrances to the palace were opened for pedestrians to freely pass through the internal patios. This gesture was proclaimed as the "recuperation of a democratic tradition" since those same patios were publicly accessible before 1970 . They had been closed, even if not completely, as a security measure by Allende's government after the Commander-in-Chief of the military had been killed in an anonymous armed attack in the streets of Santiago. They remained closed throughout the dictatorship. So in 2000, the public reopening of this space aimed to symbolize the recuperation of the traditional character of the Chilean House of Government, which was transparent and "open" to all Chilean citizens. The measure had a great impact on the population, and thousands of people visited La Moneda in the following days.

Three years later, coinciding with the commemoration of the $30^{\text {th }}$ anniversary of the military coup, Lagos carried out the first physical interventions in the Palace. These were minor interventions, but with an important symbolic significance for the battle of memory. One of them consisted in the installation of two plaques and two paintings commemorating Allende, in two different parts of the building. The plaques were hung in the place that was supposed to have corresponded to where Allende's office had been before Pinochet's restoration of the palace. This intervention generated some polemics: right-wing politicians refused to participate in what they considered an apology of the president that had been responsible for the worst crisis in Chile's history, while some exponents of the Christian Democrat Party publically disagreed with those initiatives, considering them to be an expression of a partisan view that was being imposed on a symbol that belonged to the whole of society (Bianchini, 2012: 257- 
262). Notwithstanding the polemics, the plaques and paintings stayed where they had been installed.

The second and most media-based gesture of the $30^{\text {th }}$ anniversary of the military coup was the restoration of the Morandé 80 door, the only change that would be visible from the outside of the palace. It was a personal initiative of the president, and to some extent it was in line with the "engineering" of memory rehearsed since 1990, even if in a much different context. Although the date of door's inauguration -September $11^{\text {th }}$ - had a clear symbolical charge, it was also presented as a "recuperation of traditions", similar to the meaning given to the patios' re-opening 2000, which could be labeled as what Hobsbawm calls the "invention of tradition" (1983). In this way the door was transformed into a symbol able to address the whole nation, in the name of a common heritage (Fig.2).

The door situated on Morandé Street was built at the beginning of the twentieth century and was used as a private access point to the president's office, so that heads of state would not have to pass through the main entrance and receive protocol salutes every time that the president entered the building. Until the military coup, the door had never possessed additional symbolic meaning. As I have mentioned earlier on, the door was eliminated during Pinochet's restoration project, with the purpose of restoring the building according to the original drawings from 1800. Nevertheless, in 2003, its restoration became a symbol of the restoration of a democratic tradition, which had been interrupted and erased by the dictatorship. In line with this, the national press began to refer to the door at Morandé 80 as "The Door of Democracy". ${ }^{17}$ The Council for National Monuments authorized the intervention, under the argument that the restoration of the door would "restitute to the traditional that the building had during the Republican era"18 and recommended that the small hall created by the reconstruction of the door could be used to remember "some historical event" of national history in order to give more importance to the space. The Council made no explicit reference to the bombing of the palace or to Allende's death. Therefore, the idea was not to reconstruct the door so as to reproduce the characteristics it had in 1973, but to create a new door that harmonized with the rest of the building's entrances and that were based on the existing drawings and documents from 1923 onwards.

According to this approach, the small hall derived from the construction of Morandé 80 was transformed into what the tourist guides at the palace normally call the "Memorial of the Republic". It contains certain symbols of the "Republican traditions" to which it is devoted: among them, the collection of presidential coins and a manuscript from 1818 that is a draft of the Declaration of Independence, signed by Bernardo O'Higgins, Chile's Libertador. Again, there is nothing here that specifically relates to September $11^{\text {th }}, 1973$. The draft of the Independence Act is only a draft, because the official document was lost in the bombing of 1973; however, this detail has not been recorded in the "Memorial of the Republic". Among the presidential coins displayed there, the symbol of Pinochet's government is absent, not be-

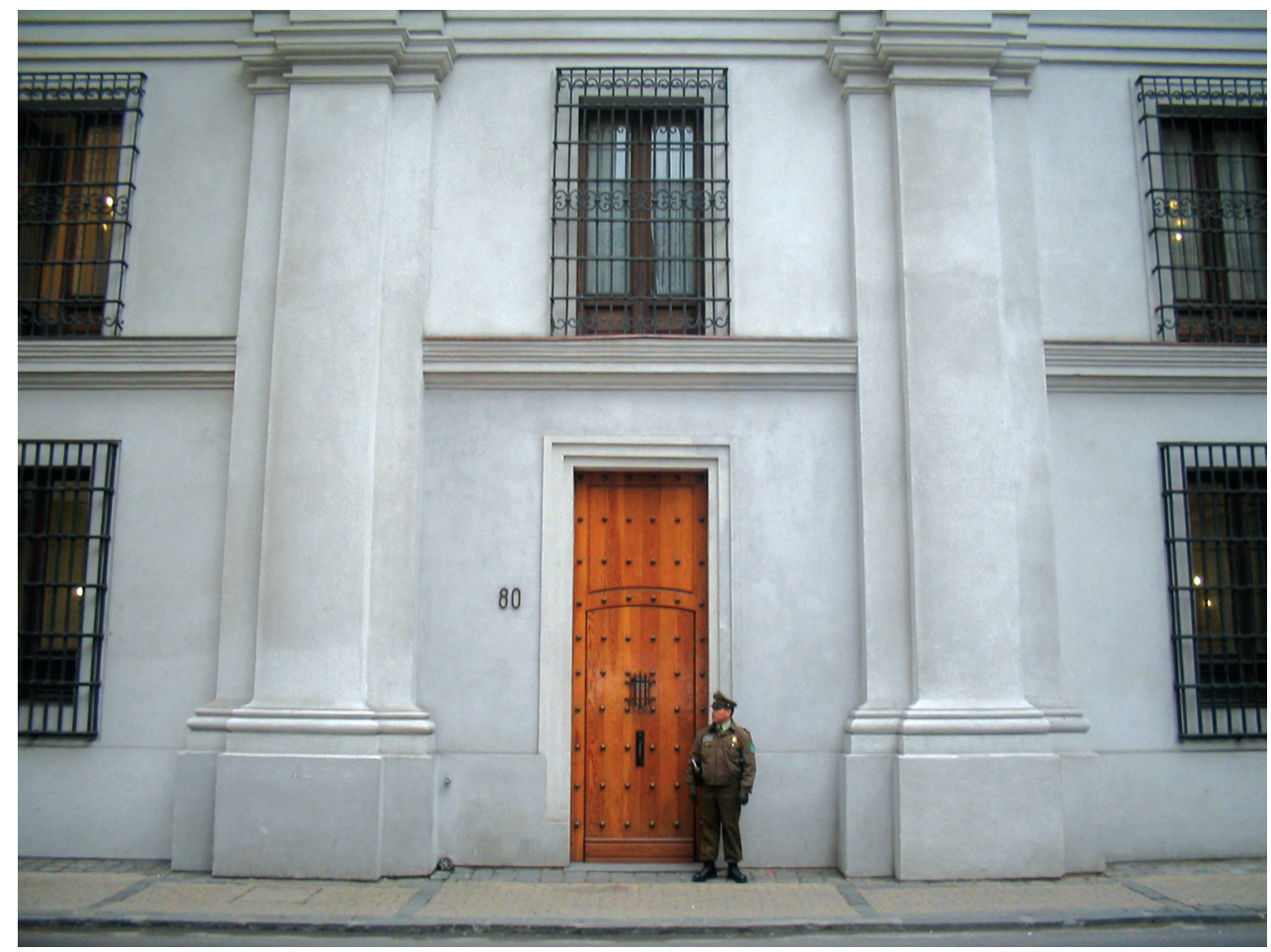

FIgURE 2: Morandé 80 door, on the Eastern side of the palace (2007). Author: Carlos. Source: Wikimedia Commons [CC-BY- SA-2.5] 
cause one did not exist, but because, as the guides explain, the Palace is only fit for those presidents that were "democratically elected". The bullet holes from the shootings found by the construction workers during the restoration of the space have not been conserved or displayed in glass cabinets, as the director of the Council for National Monuments had proposed to the government, instead they have been erased. ${ }^{19}$

Paradoxically, official memory has institutionalized a symbol whose significance was related to the bombing of La Moneda. However, by doing so, it has eliminated all the marks of that crime, even those that are invisible. Therefore, Morandé 80 as a monument does not commemorate 1973, but a Republican tradition from the twentieth century in which the president used to enter the palace through this backdoor entrance. The door was reconstructed in the same place where it used to be before the bombing, however without any inscription or plaque serves as a reminder of Allende's death or the detention of its collaborators. The only indirect reference to these events exists in the brass numbers located on the wall to the left of the door. These numbers did not exist before and now they carry a meaning only for those who are aware of its history. It is a "mute memorial", that refers to a social memory that associates this site with the September $11^{\text {th }}$ bombing, but that does not get recorded on the new door. On one hand, this was the solution that was adopted in line with Chile's "reconciliation" discourse and that permitted to fit a conflictive memory into a national monument. The absence of an external plaque to explain the reason for the reconstruction of the door or to commemorate those who died there, responds to a common sense shared by many Chileans. For them, La Moneda is a symbol that belongs to the Nation and that cannot be marked by the ideologies of different governments. On the other hand, the aim of Morande 80 is not to symbolize the installation of the past in the present, but its definitive closure: reconstructing Morandé 80 intended to represent the end of a period when the door did not exist -that is, the dictatorship-and resume the flow of traditions before this period of history in order to demonstrate that the difficult parenthesis of the military regime has been overcome.

In 2008, following the same discursive trend introduced by this first intervention carried out in La Moneda, President Michelle Bachelet inaugurated a second project that recreated Allende's office and the place of his death through the construction of a light gypsum structure. This new space was entitled the President Allende White Salon. The work was presented publically as a new step in the battle of memory, since the initiative sought to recover a space that had been erased by the military. At that point, this second initiative was accepted without much controversy. In contemporary Chile, Allende has become a symbol that has found a place in the Presidential Palace. When President Piñera arrived to the La Moneda Palace in 2010, he and his ministers -some of whom had once been publically pinochetistas - peacefully coexisted with the memory symbols existing in the palace.
In 2013, the government published a new book dedicated to La Moneda, the first one after the one published in 1983 by Pinochet's Ministry of Education. The book not only includes pictures and essays about the 1973 attack, but also an image of the inauguration of Morandé 80. It also discusses the "President Allende Salon" among the rest of the palace's facilities. Nevertheless, in its narration of the "historical events" of the building, the book defines Allende's government as a period of "crisis and breakdown", and it explains the coup by stating that the military decided to intervene "when the fundamental institutions were violated", so that on "the September $11^{\text {th }}$, 1973, La Moneda was once again a victim of the drama that the Republic had been experiencing" (Gobierno de Chile, 2013: 60-64). It is an explicit interpretation of recent history that is closely related to the "memory of salvation" installed in 1973. The strange coexistence of this kind of interpretation with some of the more outstanding symbols of the "memory and human rights" public discourse demonstrates that the transformation of the violent past into an element of National Heritage is not free of ambiguities and that this transformation is made possible only through important, specific omissions. In the case of La Moneda, it is evident that the present national memory regarding the violence of the past does not imply a shared interpretation regarding the historical meaning of Allende's political project nor regarding the reasons why the 1973 coup took place.

\section{HETEROTOPIAS OF THE PAST}

The second building I will discuss as an example of heritagization of past state violence is Chile's National Stadium. In the first two months after the military coup, Chile's most important stadium was converted into a huge prison camp that held around ten thousand people, although the exact number is not known. In the stadium, massive detentions of individuals took place in the context of the wave of repression that followed the military coup. Detainees included political leaders and trade unionists, students, industrial workers, but also passers-by arrested after curfew, youngsters caught writing slogans in the street, or whoever was found to be suspicious. In the different facilities throughout this sporting complex, many people were tortured and killed.

The National Stadium was not a secret detention center. On the contrary, everyone knew that people were taken there and that every day hundreds of people gathered at its entrance asking for information about their relatives. Because of its visibility and the simplistic strategies used by the military to hide the exercise of repression, the stadium also became an international symbol of what was happening in Chile. Nevertheless, in November 1973, after prisoners were moved to other detention centers, the stadium resumed its normal activities, as if nothing ever happened. Furthermore, in that same month, a bizarre football game took place in the stadium: Chile's national team won a game when its opponent, the Soviet Union's national team, was absent due to its refusal to participate in the 
match, a move which was a clear, public denouncement of Chile's military government. Nevertheless, thousands of spectators attended the "match" -one goal in a half-deserted field- and applauded the Chilean team's victory (Montealegre, 2003: 67). According to the state's official discourse, what had only very recently occurred in the stadium was simply an issue of "communist propaganda".

In 2003, the National Stadium was declared a "Historical Monument" in the "Memory and Human Rights" category. Since the 1990s, people have organized annual candlelight vigils at the stadium on the anniversaries of the military coup. However, the irruption of the public memory of its horrible past came later, after Pinochet was detained in London. In 2000, the first autobiographical book written by an ex-prisoner of the stadium was published (Cozzi, 2000), and that same year the filmmaker Carmen Luz Parot started collecting, for the first time, the testimonies and documents about the period in which the stadium had been used as a prison camp (Parot, 2002). In 2001, Parot organized the inauguration of the first commemorative plaque at the main entrance of the complex. Some political authorities participated in this inauguration, even though it was not a state-sponsored event. ${ }^{20}$ Some months later, the media showed images of Judge Guzman visiting the stadium during the investigations of the disappearance of Charles Horman, an American journalist detained at the stadium in 1973. Guzman's investigation brought about many other testimonies of people who had been detained in the stadium, which made him consider opening a specific line of investigation regarding the site's use during the dictatorship. ${ }^{21}$ The difficult past, that up until that point had been limited to the realm of personal, familial memory, slowly became a public murmur.

In December 2002, within this context and inspired by the discovery of inscriptions made by prisoners in one of the stadium galleries, a group of people started the $\mathrm{Na}$ tional Stadium, National Memory Project, which sought to preserve these traces and create a "Memory Museum" in a building to be built in the stadium complex. ${ }^{22}$ The initiative soon transformed into an urgent demand, confronting the proposal of the right-wing oriented mayor of the municipality that suggested that the building be demolished in order to avoid the public disorders provoked by football matches and inflicted onto residents. ${ }^{23}$ As a reaction to the mayor's proposal, a group of people involved in the National Stadium, National Memory Project proposed the stadium be declared a National Monument, which was ultimately accomplished by a decree issued from the Ministry of Education on the $30^{\text {th }}$ anniversary of the military coup. ${ }^{24}$

Through this declaration, the stadium attained its national heritage status. The first interesting aspect of the process of attaining this status is that, even though the stadium was classified under the "Memory and Human Rights" category, its inclusion as a National Monument was based on a series of considerations that not only had to do with its fate during the dictatorship, but with the broader history of the building. According to the document, its patrimonial value was based on its history as an important national center for sports and large-scale events, and on its characteristics as an outstanding example of modern architecture in Chile. The construction, an emblematic public work from the late 1930s, had never before been considered an element worthy of heritage conservation, and up until the last decade, could simply have been demolished. The reflection on its value as a document of past state violence has thus transformed the meaning of the place into a wider set of terms and, in this new perspective, the human rights violations that took place there are considered to be only one episode in the stadium's history that is worthy of being remembered. One year later, the Council for National Monuments published a book that consolidated this view. The patrimonial value of the new Historical Monument is defined according to three spheres: History, Sports and Architecture. "Of course we know that we are faced with contradictory values", says the introduction, "but a nation cannot be constructed denying its own past or hiding its wounds, but neither can it take shelter in them permanently" (Consejo de Monumentos Nacionales, 2004). Through this shift, the traumatic memory that had originated the process of valorization that the stadium underwent was somehow relocated inside the normal historical process and among other historical events. This patrimonial valorization has produced other non-institutional initiatives related to the new monument. For example, the stadium has been recently the object of an academic project that points to the further diversification and democratization of what is conceived as the "historical value" of this public site. It is an online "open archive" made of images from whoever can donate them, and through this collection it seeks to build a new history of the Stadium, through a multitude of personal and collective remembrances linked to this place. ${ }^{25}$

The second interesting aspect of this process has to do with the memorialization process that began after the $\mathrm{Na}$ tional Stadium became a Historical Monument. The 2003 decree required that some specific elements -including, the central coliseum, two locker rooms and an access tunnel to the velodrome- be granted special protections. It also declared that these sites could be used to memorialize the "grave events" that had taken place there. In reference to the management of these sites, the stadium's development as a heritage site has been similar to what has happened to other detention centers that have been converted into memorials. From the perspective of memory politics, these kinds of initiatives are part of what the Chilean state considers to be forms of "symbolic reparation" to the victims. This kind of reparation has existed since the very beginning of the transition as a measure recommended by the Rettig Report, and it was reinforced by President Lagos in a governmental policy specifically designed on the $30^{\text {th }}$ anniversary of the coup (Lagos, 2003). According to the "reparation" approach, victims should play the central role in memorialization projects. In the cases of Villa Grimaldi or Londres 38, associations of victims linked to the site have become the creators and the moral guardians of the memory of each place. They also manage each site according to its specific principles and ideas. The case of the 
National Stadium was peculiar in this sense, and its adjustment to the "reparation" model was complicated and generated various conflicts. Due to the stadium's short life as a detention center, a specific association of victims clearly linked to the place did not exist. Most of those who were imprisoned there had joined associations linked to the camps, like Chacabuco, where they were later imprisoned. As a consequence, the stadium became an orphan. In addition, the stadium was also a public center used for large-scale events. A victims' association could not possibly manage such a large place, in which its normal life as a public stadium had to be combined with the management of the traces of a difficult past.

The campaign that resulted in the declaration of the stadium as National Monument began to fragment and disperse in the following years, mainly due to an internal conflict between two different memorialization projects, one led by a group of architects and another defended by an association of ex-political prisoners. Architect Valentina Rozas, who has investigated this process, argues that the group of architects involved in the campaign proposed a project that aimed to intervene in the complex of the stadium as a whole, complementing its patrimonial valorization and urbanistic redefinition with a memorial project that needed to represent the State's public condemnation of the crimes perpetrated there. In contrast, the association promoted a project centered on the construction of isolated memorials in selected sites within the complex, which, according to Rozas represented the literal memory of the victims, instead than an exemplar public message (Rozas 2013).

Finally, the memorialization project was led by the representatives of the association of ex-political prisoners (Asociación metropolitana de ex presos politicos), that in the past personally managed the construction of memorial sites in the stadium, as has occurred with many other sites that were used as detention centers during the dictatorship. Without denying the effort and commitment of the work done by the association, it is nevertheless distinctive how an emblematic symbol of a national and even international memory linked to dictatorial violence in Chile has been managed in a form of almost personal ownership by a small group of people, who became the public referents related to the difficult past of this particular place. The construction of memorials has been negotiated directly by the association with the corresponding authorities -the Council for National Monuments, the Ministry of Public Works and the Institute for Sportsand the process has not been opened to the general public nor has it involved any other actors. The association has a small office on the stadium's grounds, from which they manage their sites and organize related activities -such as guided tours and the recalling of testimonies. As it states on the entrance door of the small office, the association's presence in the sports center falls under the label of "human rights". Their activities do not have anything to do with the rest of the events organized in the stadium. As such, the "human rights sites" appear to be forms of heterotopias of the past within the sports complex. That is, as in the concept conceived by Foucault (1997), at these sites from the past are enclosed or confined, though the rest of the place is somehow released from it.

At present, some memorial interventions have already been carried out, while others are still ongoing, especially due to the lack of financial support of these initiatives. The most impressive intervention is the project that is located inside the central coliseum. In 2009, in the context of restoration work carried out in the facility, the seats of the coliseum were substituted with new ones. The memorial consists in the conservation of a few square meters of the old wooden seats, which were later surrounded with glass panels (Fig.3). During football games and concerts, the memorial is visible to the public from every point of the coliseum. Nevertheless, there is no inscription or plaque that explains why these old stands are still present. Their power to evoke the violence that occurred there is connected to a widespread social memory linked mainly to photographs from 1973 that include the wooden seats occupied by prisoners and armed men. As in the case of Morandé 80, the messages can only be understood by those who know how to decipher them and by those who can recognize that the new memorial represents a public acknowledgment of something that occurred in the past.

Since the memorials at this site are located in a place that normally functions as a stadium, on certain occasions their daily life are interrupted by events that have nothing to do with the recent past. These events also call into question these memorials' functions as heterotopias of past violence. For example, the coliseum memorial was damaged during the uproar that took place during a recent football match. Following the reaction to that event illuminate the social meaning that "Memory and Human Rights" heritage has acquired. Although the damage caused during the football match was not serious, some media outlets reproduced visual footage over and over in order to boost public indignation and condemn the football fans' uncivil behavior as being responsible for the damages provoked. Immediately, political authorities and human rights organizations sent solidarity messages to the representatives of the association of ex-political prisoners. At the same time, the organization of football fans made a public statement declaring that it had been an accident that bore no political intention, and the president of the association responded by suggesting that they would organize a special guided tour for those youngsters in order to educate them about the symbolic meaning of the memorials. ${ }^{26}$ While in the daily life of the stadium these kind of sites are heterotopias where the past is enclosed as a form of "reparation" towards the victims, at the same time the pedagogy of memory that they carry out through different type of activities is generally accepted as one of their legitimate functions.

The "reparation approach" characterizes "Memory and Human Rights" heritage as something whose ownership and management is attributed mainly to the victims and their representatives, since they were the ones who were directly affected by human rights violations. Nevertheless, the consecration of their public role as represent- 


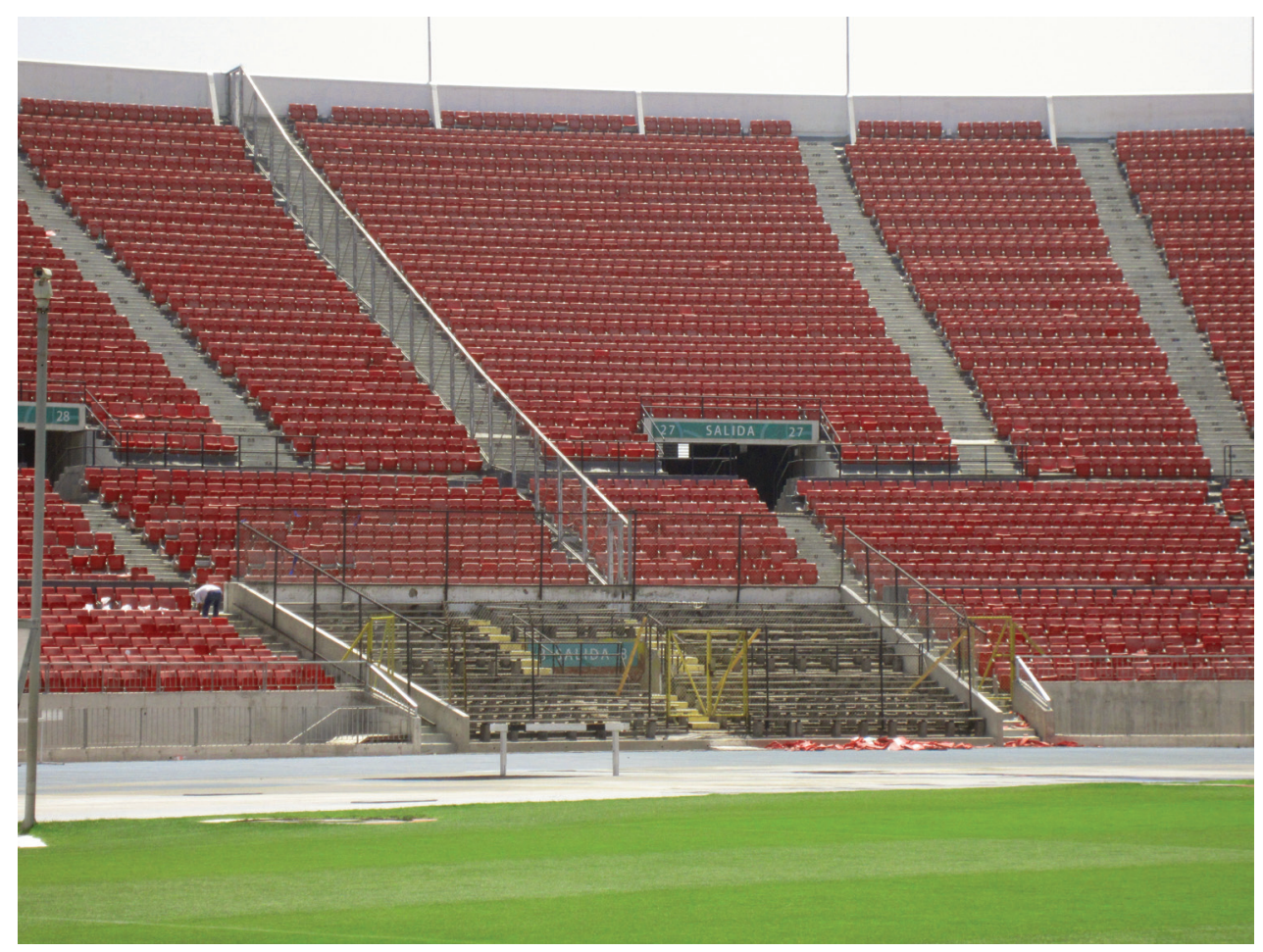

FIGURE 3: Memorial site in the stands of the central coliseum (November 2013)

atives of a memory and human rights cult can serve the interests of different actors and discourses. This is why the damages at the coliseum memorial could be used by right wing media outlets that normally would not pay much attention to memory issues as an opportunity to criminalize football fans. This argument also helps to understand the position of the other memorials that have been built on the stadium grounds, especially those located in the swimming pool locker room and at main entrance. Both of them were inaugurated in 2013, under the right-wing government of Sebastian Piñera, and their construction was negotiated directly between the association and state authorities. Although the whole process of heritagization and memorialization of past violence in the stadium was initially promoted by the socialist governments of Lagos and Bachelet, the names of Piñera and his Sports Minister appear in the inscriptions that go with the memorials. The presence of these names was surely a disturbing surprise for many of those who attended the inauguration, since Chile's right-wing political parties have traditionally been the natural enemy of those involved in memory battles. Yet they demonstrate that the circumstances of these battles have changed: "Memory and Human Rights" heritage has become part of a state policy that now can be promoted by governments with very different political orientations.

The fact that a right wing government can use memo$r y$ and human rights heritage as a political resource requires the historical de-contextualization of the suffering that the monuments commemorate. It also requires the absence of any public statement regarding the direct and indirect responsibilities that stem from the crimes committed during the dictatorship. As such, the memorial that was built at the main entrance to the stadium was designed as a piece of abstract art that, according to the side inscription, is a "homage" that the government offers to former political prisoners, with a clear reference to the association that promoted the initiative (Fig.4). The memorial includes no other details or explanations, nor does it make reference to the dates, the number of prisoners, their identities or to the historical context of their imprisonment. This memorial is a good example of the "reparation approach" that has permitted the fluid collaboration between two public actors -the right-wing government and the victims - that otherwise would not have found a common ground on which to collaboratively work. From a memory battle perspective, the existence of these memorials in the stadium represents a victory over oblivion and those who negate the crimes committed during the dictatorship. Nevertheless, it is a victory that appears so consensual and so free of conflict that it produces an odd feeling of emptiness -a sensation, perhaps, that the proclamation of this truth in public spaces has somehow lost its political meaning.

\section{A POETIC RECUPERATION}

The violence of dictatorship was directed at eliminating its enemies, partly through the eradication of their symbolic references, their material culture, their scientific production and their cultural settings. What happened to the Gabriela Mistral Cultural Center after September $11^{\text {th }}$ 


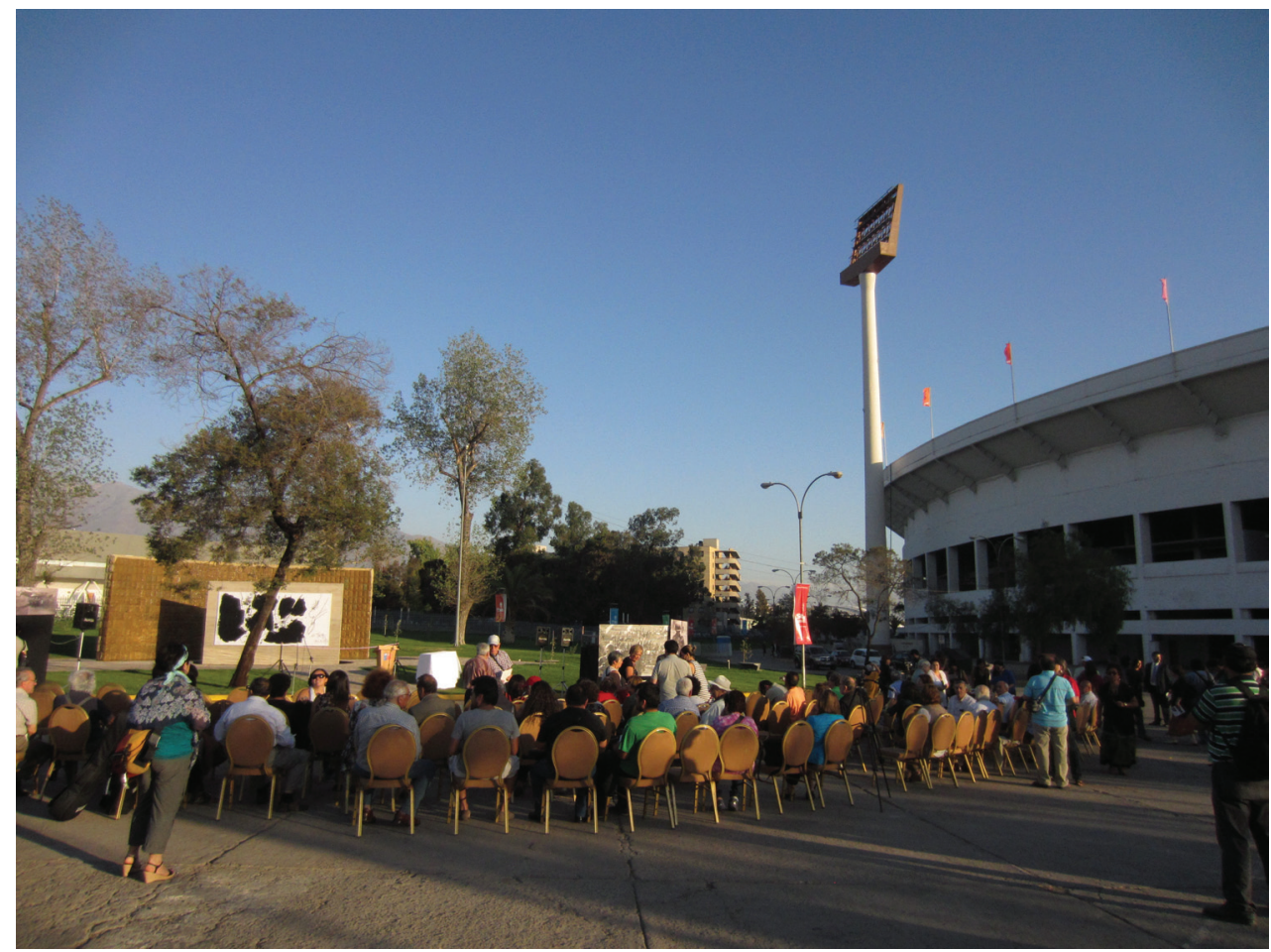

FIGURE 4: Inauguration of a memorial at the main entrance to the National Stadium (March 2014)

should be interpreted within this context. The huge building, made of a rectangular flat structure and a tower in the center of the capital city (Fig. 5), was constructed between 1971 and 1972 to host the Third United Nations Conference on Trade and Development (UNCTAD III). During its construction, the building became an important, widely recognized symbol of Allende's government. It represented the "spirit of work, the creativity and the effort of the Chilean people", as stated in an inscription which was originally located in one of its internal patios. As President Allende stated in the inauguration of the Conference in 1972, "the devotion and fervor by which the Chilean people have constructed this building symbolize the devotion and fervor with which Chile wants to contribute to the construction of a new humanity $[\ldots]$ ". ${ }^{27}$ The year after the conference, the building functioned as a cultural center. It was used to host assemblies, exhibitions and workshops, and it used to have a large and popular dining hall. It was an emblem of Allende's government and its supporters.

The building was occupied the day following the coup. Shortly after, while La Moneda was still unusable, the military junta decided to locate its House of Government in the former cultural center. The building's name was immediately changed to honor a historic politician dear to Pinochet, Diego Portales. ${ }^{28}$ The building's entrances and its large windows were closed with bars and metal panels. Pinochet established his office on a high floor of the tower and one month after the coup he was already speaking to the Chileans from the renamed Diego Portales building. The whole neighborhood dramatically changed due to new security measures. Access to the zone was only permitted to residents, and armed soldiers were placed in the streets nearby. With all this, the Cultural Center became unrecognizable and virtually disappeared.

The Diego Portales building became a symbol of the power of the military junta as well as its most important public stage. In the main assembly hall, an area that had hosted United Nations delegates only a few months earlier, a large inscription with the text "Chile: 1810-1973" was installed. The inscription established a clear parallel between Chilean independence and what members of the regime called the "military pronouncement". This inscription would serve as a background to Pinochet's public speeches for many years. Besides, during major public commemorations, such as the celebrations on the September $11^{\text {th }}$, the Diego Portales building was chosen as the main site for military parades. When Pinochet moved to La Moneda in 1981, the building continued functioning as the headquarters for the Military Junta, and from 1990 onwards, it was the home to the Ministry of Defense. Up until today, the tower is still occupied by uniformed military personnel that work in the Ministry of Defense. The space remains inaccessible, separated from the rest of the neighborhood by metal bars. The destiny of the rectangular building, however, has been different. In the late 1990s, it was used as a conference center. Nevertheless, its enormous structure made of concrete and steel, and the deterioration of the main entrance's surroundings made it an unpleasant place that many Chileans considered one of the worst buildings in the country. The building was underused and uncomfortable, and most of all it evoked the years of dictatorship. 


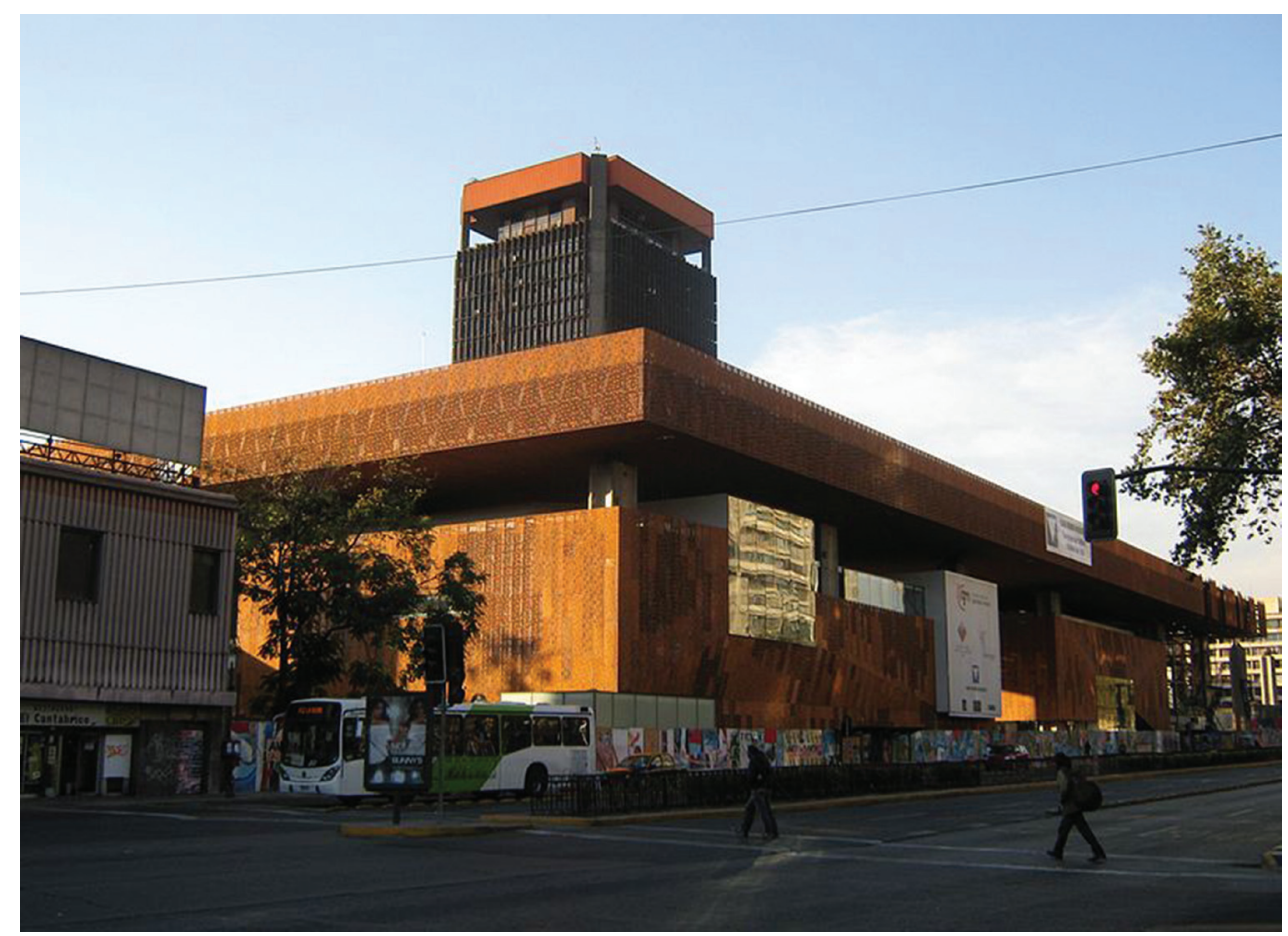

Figure 5: GAM Cultural Center (2010). The picture shows the two buildings -the tower and the main rectangular construction- that together form the complex. Author: Penarc. Source: Wikimedia Commons [CC-BY-SA-3.0]

The turning point in this story occurred after a fire that affected the plenary hall in March 2006. The images of the fire greatly impacted Chileans, and in the following months, the building appeared in interviews, articles and columns that for the first time spoke about its history and its construction. The fire provoked an "irruption of memory" that generated a sort of social campaign - even if it was not centralized nor coordinated by any specific group - that, for the first time, demanded that the building be "restituted" to its original public function. The main protagonists of this campaign were architects -some of whom had worked on the original construction and younger professionals that had never seen the original building. They wrote articles and spontaneously presented proposals to the Ministry of Defense. ${ }^{29}$ In October of the same year, an anonymous urban intervention placed official looking signs in the nearby streets that referred to the building as the "Gabriela Mistral Cultural Center", thereby recovering the structure's original name. ${ }^{30}$ Soon after, when the Ministry announced the possibility of selling the building, even El Mercurio -the most important right-wing newspaper- was forced to recognize that the authorization to sell the building was expected to provoke resistance by those "who wanted to preserve the historic value of the building constructed under the presidency of Salvador Allende". ${ }^{31}$

Obviously, there were different opinions about the destiny of the damaged building. Many architecture firms proposed reconstruction projects that appeared completely indifferent to the "historic value" of the building, while others argued that the building was so ugly and useless that it would have been better if it had burned completely. ${ }^{32}$ Nonetheless, the government, then led by Michelle Bachelet, was sensitive to the demands of those who wanted to recuperate the Cultural Center, and in July 2007 the Ministry of Public Works called an international competition for architectural proposals. The call for projects underlined the historic and symbolic relevance of the building, with a large chapter dedicated to a "historic review". The explicit aim was to recover the "original sense of the building" and its public function, adapting its installation to the needs of a contemporary cultural center dedicated to theatre and the visual arts (Dirección de Arquitectura/Ministerio de Obras Públicas, 2007). The work was inaugurated in 2010 as an important public effort for the commemoration of the $200^{\text {th }}$ anniversary of national independence.

The restoration project aimed to "take the ideas and qualities of the original project, and freely reinterpret them in a contemporary way, to construct a new program for the building" (Fernandez, 2010). The work included a fine arts curatorship to be selected through a public competition and financed by the government. The idea goal of this curatorship was to design a conceptual framework for decorating the space with artworks that would harmonize with the architectural approach as an "expression of historical memory and recuperation of the poetics of the original project". (Llano and Varas (eds.), 2010: 19). The call for projects established that the curatorship had to rescue and value the artworks that were integrated in the original building, many 
of which were lost or destroyed when the military occupied the building. Those artworks that could be found would not only decorate the new building, but would also constitute what the web page of the cultural center now considers its "patrimonial collection".

A second objective of the curatorship was the installation of new artworks that would be in dialogue with the history of the building. The selected project focused on the concept of "genealogy", and fixed its principal aim on the "reactivation of the memory of the building", defining itself as an "expression of resistance against oblivion", and a "platform for the search for our identity" (Llano and Varas (eds.), 2010: 22). The traces of this identity had to be found, according to the curators, in the historical processes, as well as the political, cultural, architectural and artistic ones, that had made the Salvador Allende's government and the construction of the building possible. According to the timeline eventually installed in the library of the cultural center, these processes developed throughout the twentieth century. They included histories and achievements that had somehow been erased by the dictatorship and that now had to be rescued, with the intention of establishing new genealogies for the present. It is interesting to note that this project shares its basic approach with a number of other artworks that have been carried out in recent years by young Chileans and that, in many cases, have been financed by state programs. That is, at the moment, there exists a line of research and thinking about the recent past that aims to "rescue" the story of specific public projects -especially in the fields of tech- nology, art and architecture- that were interrupted in 1973 and that have been mostly forgotten. ${ }^{33}$

While the renovation of the cultural center was initiatied by Michelle Bachelet, it was inaugurated in 2010 by President Piñera. In his speech the president said that the building "had been the witness of conflicts and fractures that have crossed our country, and now, after being destroyed by fire, it is born again to be a space where the different positions and thoughts that live and give life to our homeland can coexist". ${ }^{34}$ Today, the Gabriela Mistral Cultural Center, which has adopted the acronym GAM, is a lively and busy public space, with theatre and dance performances, a pleasant cafeteria, a bookshop and a fancy wine shop, among other services. When the patios are not rented for cocktail parties and other events, they are used by youngsters to rehearse hip-hop dance or make use of the free Wi-Fi. There is also a free service that provides guided visits of the grounds and that introduce visitors to the building's main characteristics, its history and its artworks. The concept of culture that is promulgated through these activities has little to do with the one on which Allende's cultural center was based, yet it is again a public and open space in a country where public spaces and facilities are not very common. As President Piñera said, the cultural center is now a place that belongs to all Chileans, no matter what they think about the government of President Allende.

Nevertheless, the new identity of this place also required specific selections. Similar to La Moneda, there is nothing here that is a reminder of the Diego Portales building, nor of the 1973 coup. Among the pieces in-

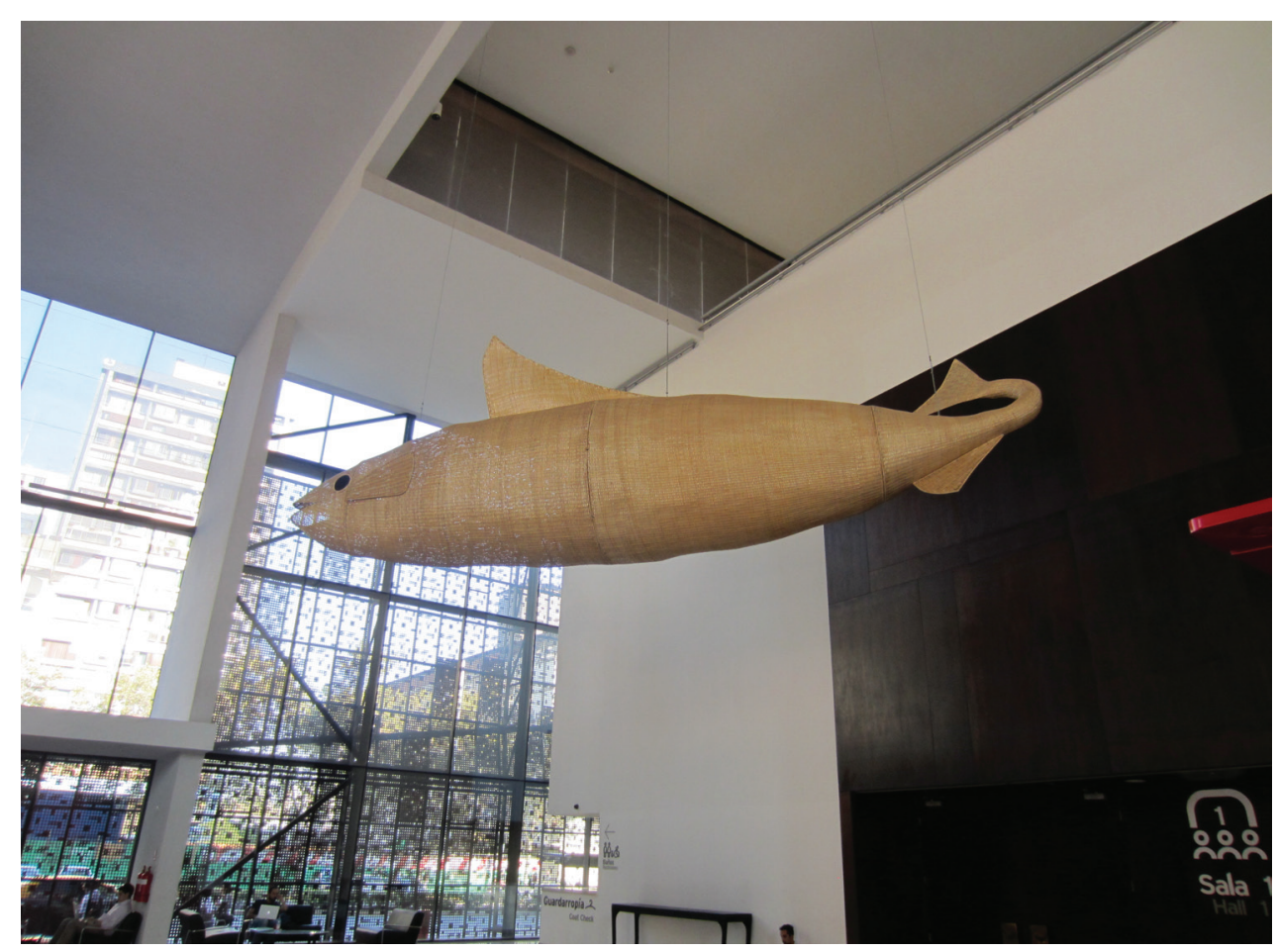

Figure 6: One of the art works of the patrimonial collection of GAM Cultural Center. It is a reproduction of an original piece that was lost after 1973. The reproduction has now been installed in the main entrance to the building (April 2013) 
stalled in curated artworks chosen to be included in the new cultural center, the only object that refers explicitly to the events related to the coup is an inscription located in one of the patios that reproduces the text of the original plaque from 1972 mentioned earlier, that describes the building as a representation of "the work spirit, creativity and effort of the Chilean people". The new inscription also makes note that the original plaque was "removed and probably destroyed after the 1973 coup". Besides that, the new building shows no record of the Pinochet era. To some extent, it is as if the dictatorship never passed through the space -as if there was a natural continuity between Allende's building and the building in its present state. In this way, one could say that the historical fracture has been repaired. The cultural center's webpage includes an ample section about the building, with images, videos and the testimony provided by one of the architects that participated in the original 1971 construction. All of this material is now included on the webpage under the section "history".

\section{HERITAGE FOR DEMOCRACY?}

In order to formulate an open conclusion, I refer once more to the initial question of this paper that asks about the role of memory politics and heritage in the construction of a national democratic community. With regards to the recent histories of the three buildings analyzed in this paper, we can ask if and how the heritagization of past violence considered within a framework that centers on a human rights paradigm does - or does not-contribute to the construction of a more democratic and pluralistic society and state. Some recurrent themes in these examples of heritagization in Santiago are important in the evaluation of its success.

First, we have to consider the processes of memorialization carried out by the state. Restorations, reconstructions, acts of elimination or attempts to recover the traces of what happened in these buildings in past decades are layers of public memory. They represent consecutive uses of the past on behalf of the state. In addition to physical appropriating these places, the dictatorship erased and rewrote their histories in a unilateral fashion. By contrast, the processes of heritagization that have taken place in the past decade in the name of memory and human rights have always emerged out of initiatives or demands expressed by civil society groups. These stories demonstrate that the progressive installation of a human rights paradigm as the hegemonic discourse regarding Chile's dictatorial past is related to the visibility and legitimation of new actors in public sphere. The state has addressed these demands in different ways, and in these processes, heritage has not only been an instrument for the state's political appropriations of the past, but has also offered different actors, citizens and institutions the opportunity to debate and negotiate how the past will be put to use in the present, allowing for wider forms of participation in the management of what is public.

Second, we need to look at the material shapes that have resulted from these processes, as well as analyze the messages regarding Chile's recent past that these places provide their visitors. The three stories discussed in this paper illustrate how the official human rights discourse is always constructed around ambiguities. These ambiguities become especially evident when focusing on what monuments do not say. In particular, these institutional public places, either do not say anything about dictatorship, erasing its marks to repair the fracture of National History, or reduce the memory of the dictatorship to a memory of horror, that does not require an explanation about its origin and its reasons, and that is confined to specific sites, and managed by specific groups, mainly the victims. In these buildings, the dictatorship then becomes a parenthesis, in time and space, somehow external to the traditional spirit of the country that these places intend to represent. In this sense, the public cult of memory and human rights implies the de-contextualization of past violence from the historical processes that generated it and therefore does not generate complex understandings regarding the long-term conflicts and cultural beliefs that underpinned and justified those crimes. This is at least problematic since, as Tzvetan Todorov claimed in a recent conference in Santiago, the only way to prevent the repetition of past violence lies in the comprehension of its nature and reasons (Todorov, 2013).

Another important aspect, related to the previous one, has to do with the consequences that these processes can have on the meaning that present society gives to recent historical experience. These buildings show that, in the name of memory and human rights, heritage politics can address the transformation of a conflictive experience into what is perceived as history, and therefore accepted as something separated from the present. While this shift surely is a necessary process that allows societies -and individuals - to overcome a problematic experience, at the same time it shows that state memory politics can perform the closure of processes that, in many ways, are actually still open, and that have to do, among other things, with public attribution of responsibilities and with the implementation of justice. Probably the most impressive feature of Chile's post-dictatorship memory processes is the gap that exists between the efforts that the state dedicates to the cult of memory and human rights -as the management of urban heritage demonstrates- and the difficulties it continues to have when having to publicly condemn and prosecute those responsible, be they representatives of a military institution or civil society, for the crimes perpetrated during the dictatorship.

Finally, these cases demonstrate that the heritage politics that transform the dictatorial past into an episode of history are the expression of an institutional memory that now shares public space with a great number of different non-institutional actors, whose memory politics and memory practices often aim to evoke the past to transform the present. We have seen how heritage memory politics can promote a wider revision of national history and identity, thereby allowing the appearance of other historical content that is "discovered" and used by different kinds of actors in order to establish new genealogies for understand- 
ing the present. These cases suggest that the urban heritage memory politics' greatest contribution to the construction of democracy does not really lie in official narrations and pedagogies, but on the ability of non-institutional actors to occupy - physically and symbolically- the spaces that the official cult to memory and human rights generates, to develop new initiatives and forms of reflection that explicitly seek to influence present political decisions and to establish memory and human rights as an issue that is not only relevant to the victims of the past, but also to the whole of present-day society.

\section{NOTES}

1. This article is part of the research project: Patrimonio urbano y memoria: un estudio comparativo entre Madrid y Santiago de Chile (CONICYT/FONDECY/Post-doctorado N.3140430).

2. A critical and systematic discussion regarding a sociological perspective on the international global human rights paradigm is developed by Daniel Levy and Natan Sznaider in their contribution to this volume. This critical approach also appears recently in Southern Cone memory studies. It was first developed by Elizabeth Jelin (2013), and it is the core idea of the virtual forums organized in 2014 by the Nucleo de Estudios sobre Memoria of the Argentine Instituto para el desarrollo Economico y Social: http://memoria.ides.org.ar/pagina-foros [accessed 08/ September/2014]. A similar critical perspective -although it does not explicitly refer to human rights as a paradigmatic framework- was put forth by Tzvetan Todorov in a conference he gave at Santiago's Museum of Memory in November 2012 (Todorov, 2013).

3. In 1998, the accusation against general Pinochet stated that "the group that was prosecuted and harassed was formed by those who didn't adjust to the type that the promoters of repression considered proper of the new order that had to be established in the country": Auto de la Audiencia Nacional (España), de 5 de noviembre de 1998, por el que se considera competente la Justicia española para perseguir delitos de genocidio, tortura y terrorismo cometidos en Chile: http://www.derechoshumanos. net/jurisprudencia/1998-11-05-AN-\%28Pinochet\%29-AutoCompetencia-Spain-Genocidio-Chile.htm\#FD1 [accessed 30/ September/2014]. A discussion on the debates regarding the origins and conceptualization of the concepts of "genocide" and "genocidal practices" and their use in the study of recent military dictatorships in Latin America and Spain can be found in Míguez (2012).

4. The reference to the Chilean case in the discourse produced through social activism employed for the recuperation of historical memory in Madrid has been underlined by Capdepón (2009). Also, the analysis of some Chilean initiatives in this field have been analyzed in the 2004 preliminary study for the design of the institutional Memorial Democrátic in Catalunya (Vinyes, 2004).

5. The 1988 referendum was part of the transitional program designed by the military government. Citizens had to choose between the option SI -having Pinochet as president for another eight years- or NO, which meant to have elections with different candidates. The first option obtained $43.01 \%$, the second $54.71 \%$.

6. El Mercurio [EM] "Discurso de Augusto Pinochet en el Edificio Diego Portales" and "Misión emprendida en 1973 ha sido superada con creces", 8 March 1990: C1 and C10.

7. "Querer no ver" (Wanting not to see) is the title of an urban performance that was organized in the center of Santiago in 2013 , coinciding with the $40^{\text {th }}$ anniversary of the military coup. The basic idea of the performance was to respond to public declarations made on that occasion by former Pinochetista public figures, who argued that they supported the regime because they did not know about human rights abuses that were committed. El Mostrador, 13 September 2013: http://www. elmostrador.cl/cultura/2013/09/13/la-cicatriz-humana-quebroto-en-el-centro-de-santiago/ [accessed 08/September/2014].

8. Gobierno de Chile, ArchivoChile "Declaración de principios del Gobierno de Chile", 11 March, 1974. http://www.archivochile. com/Dictadura militar/doc_jm_gob_pino8/DMdocjm0005.pdf [accessed 08/September/2014].

9. On one hand, since 1978, Chile has had an Amnesty Law that can be invoked by tribunals to nullify trials connected to crimes perpetrated by the military between 1973 and 1978. Debates regarding the suppression of this law were recently put forth by Bachelet's government as a topic to be discussed in Chilean parliament in 2014. On the other hand, the human rights reports published in 1991 and 2004 do not have a judicial value and their archives are not public. According to a report by the $\mathrm{Hu}-$ man Rights Observatory of the Diego Portales University, in August 2012 there were more than a thousand processes opened up in Chilean tribunals for human rights abuses during the dictatorship, almost 200 military personnel had been condemned, and only 65 of them were effectively in prison (Observatorio de Derechos Humanos, 2014).

10. The initiative with the highest media impact was the closing down of the Cordillera Cárcel, one of the prisons where some of the most notorious military personnel tried for human rights abuses were detained while enjoying special facilities and favorable conditions. Not without generating internal conflicts in his coalition, in September 2013, president Piñera decided to close down the Cordillera Cárcel, as he reallocated ten prisoners to the Punta Peuco prison, another emblematic, but less privileged detention center for human rights abusers.

11. After 1973 , military language used the term "military pronouncement" to the describe the military coup. In this case, the shift in the use of words proves to be relevant.

12. The normalization of this category in CMN's documents is very recent. In the latest versions, it goes under the category of "Sites of memory and commemoratives monuments", that also includes monuments referring to other historical events. The label "Memory and Human Rights" refers here to the function of these specific monuments. $C M N$ "Nómina web de Monumentos Nacionales de 1925 al 3 de junio 2014", 2014.

http://www.monumentos.cl/catalogo/625/articles-22591 doc xls.xlsx [Accessed 08/September/2014]

13. Ibidem.

14. [EM] "Carta de Venecia y La Moneda", 11 November 1973: 6

15. The name is due to the physical address of the palace's side entrance.

16. The Socialist Party was part of the governing coalition. Isabel Allende, the daughter of the president, was deputy of this party.

17. La Nación [LN] "Morandé 80: puerta de la democracia", 14 September 2003: 12

18. CNM “Acta agosto 2003", August 2003: 6. http://www. monumentos.cl/consejo/606/w3-article-22464.html [accessed 08/September/2014].

19. Interview with Angel Cabeza, who was the director of the CMN from 1994 till 2006. Santiago, 04/April/2014.

20. [LN] "Placa memorial recuerda a presos del Estadio Nacional", 30 October 2001: 4

21. La Segunda [LS] "Caso Charles Horman: juez Guzmán realiza diligencias en el Estadio Nacional", 14 March 2002: 14; Punto Final $[P F]$ "El Estadio Nacional revela sus horrores", 31 May 2002: 10.

22. El Siglo [ES] "Estadio Nacional, Memoria Nacional", n 1117, 6 December 2002: 21.

23. [EM] "Sabat propone vender el Estadio Nacional", 27 March 2003: C8.

24. Ministerio de Educación "Decreto Exento n. 710: Declara Monumento Histórico el Estadio Nacional, ubicado en la Comuna de Ñuñoa, Provincia de Santiago, Región Metropolitana", 11 September 2003. http://bcn.cl/1n39a [accessed 08/September/2014].

25. Estadio Nacional, Archivo Abierto: http://www.archivoestadio nacional.cl/ [Accessed 11/October/2013] 
26. El Clarin $[E C]$ "Declaración de ex prisioneros políticos ante la destrucción de sitios de memoria en el Estadio Nacional", 28 August 2014. http://elclarin.cl/web/sindicatos-activismo/ activismo/12872-declaracion-de-exprisioneros-politicos-antela-destruccion-de-sitio-de-memoria-del-estadio-nacional.html [accessed 08/September/2014].

27. Allende, Salvador "Discurso inaugural de la Tercera Conferencia Mundial de Comercio y Desarrollo realizada en Santiago de Chile", 13 April 1972. http://www.archivochile. com/S_Allende_UP/doc_de_sallende/SAde0027.pdf [accessed 08/September/2014].

28. Diego Portales was the Minister under different charges in the first years of the 1830s. His name is normally linked to the Constitution adopted by the Chilean state in 1833, which remained active until 1925

29. La Tercera [LT] "Arquitectos llaman a recuperar edificio Diego Portales", 7 March 2006: 11. One example of the "recuperation" projects elaborated and presented in that opportunity: Colectivo Uro1.org, (2007), “QQué hacemos con el Edificio de la UNCTAD 3? Museo Internacional de Arte Moderno y Contemporáneo Gabriela Mistral. Propuesta de una Política de Estado para la República de Chile para un plan de reordenamiento y conservación del patrimonio artístico nacional en la ciudad de Santiago y su impacto". http://www.plataformaurbana.cl/ archive/2007/01/23/museo-internacional-de-arte-moderno-ycontemporaneo-gabriela-mistral/ [accessed 09/September/2014].

30. Valenzuela, Nicolas (October 3, 2006), "Intervenciones Urbanas 2.0 /Nuevo Centro Cultural Gabriela Mistral", in Plataforma Arquitectura. http://www.plataformaurbana.cl/archive/2006/10/03/ intervenciones-urbanas-20-nuevo-centro-cultural-metropolitanogabriela-mistral/ [accessed 09/September/2014]

31. [EM] "Defensa vendería el edificio Diego Portales", 19 November 2006: $\mathrm{C} 1$ and $\mathrm{C} 16$.

32. [LT] "Presenta más de 100 ideas para reparar edificio Diego Portales", 18 October 2006: 18; [EM] "Reconstruyendo desde las cenizas al Diego Portales", 12 August 2007: E2-E6.

33. Two examples of these kinds of projects: 1) Cybersyn, a project led by a group of artists, funded through the state program Fondart in 2006. It aims to recover the story of a cybernetic project developed during Allende's government to facilitate the management of nationalized industries: www.cybersyn.cl [accessed 09/September/2014]. 2) Monolith Controversies, a project that was presented as the Chilean representative at Venice Biennale of Architecture 2014, and won the Silver Lion prize in this contest. The project was about a constructive element -a cement panel- that was produced in a nationalized Chilean factory in 1972. The inaugural panel was signed by Allende and then "disappeared" after the military took power in 1973. About this project: http://www.plataformaarquitectura.cl/ cl/02-367860/monolith-controversies-pabellon-de-chile-en-labienal-de-venecia-2014 [accessed 09/September/2014].

34. El Mostrador [EMR] "Inauguran Centro Cultural Gabriela Mistral", 5 September 2010. http://www.elmostrador.cl/pais/ 2010/09/05/inauguran-centro-gabriela-mistral-obra-cultural-delbicentenario/ [accessed 09/September/2014]

\section{REFERENCES}

Aguilera, Carolina (2013) "Santiago de Chile visto a través de espejos negros: la memoria pública sobre la violencia política del periodo 1970-1991, en una ciudad fragmentada". Bifurcaciones. Revista de Estudios Culturales Urbanos, 14: 1-13. http://www.bifurcaciones.cl/2013/10/santiago-de-chile-visto-atraves-de-espejos-negros/ [accessed 08/September/2014].

Ashworth, Gregory and Tunbridge, John E. (1996) Dissonant Heritage: The Management of the Past as a Resource in Conflicts. John Wiley \& Sons, Chichester and New York.

Bianchini, Maria Chiara (2012) Chile, memorias de la Moneda. La Reconstrucción de un símbolo político. UAM/Iepala, Madrid.

Capdepón, Ulrike (2009) Historical Memory and Democratization in Chile and Spain: Between Local Discourses and International
Norms: http://www.irmgard-coninx-stiftung.de/fileadmin/user upload/pdf/Memory_Politics/Workshop_2/Capdepon_Essay.pdf [accessed 08/September/2014]

Collins, Cath (2013) "La política de la justicia: Chile más allá del caso Pinochet". In Las políticas de la memoria en Chile: desde Pinochet a Bachelet, edited by Collins, Cath; Hite, Katherine and Joignant, Alfredo. Universidad Diego Portales, Santiago, pp 279-292.

Collins, Cath and Hite, Katherine (2009) "Memorial Fragments, Monumental Silences and Reawakenings in 21st-Century Chile". Millennium: Journal of International Studies, 38 (2): 379-400. http://www.derechoshumanos.udp.cl/ddhh $1 /$ boletines observatorio/Memorials-in-Chile.pdf [Accessed 08/September/ 2014].

Comisión Nacional de Verdad y Reconciliación (1996) Informe de la Comisión de Verdad y Reconciliación. $1^{\text {st }}$ edition, 1991. http:// www.ddhh.gov.cl/ddhh_rettig.html [Accessed 08/September/ 2014].

Comisión Nacional sobre Prisión Política y Tortura (2004) Informe de la Comisión Nacional sobre Prisión Política y Tortura. http://www.bcn.cl/bibliodigital/dhisto/lfs/Informe.pdf [Accessed 08/September/2014].

Consejo de Monumentos Nacionales (2004) Tres miradas al Estadio Nacional: historia, deporte, arquitectura. Consejo de Monumentos Nacionales/Ministerio de Educación, Santiago.

Consejo de Monumentos Nacionales (2012) Nomina de Monumentos Nacionales declarados por decreto, 1925-2011. Consejo de Monumentos Nacionales, Santiago.

Cozzi, Adolfo (2000) Estadio Nacional. Editorial Sudamericana, Santiago.

Del Campo, Alicia (2004) Teatralidades de la memoria: rituales de la reconciliación en el Chile de la transición. Mosquito Comunicaciones, Santiago.

Dirección de Archivos Bibliotecas y Museos [DIBAM]-Ministerio de Educación, Gobierno de Chile (1983) El palacio de la Moneda. DIBAM, Santiago.

Dirección de Arquitectura/Ministerio de Obras Publicas [MOP] (2007) "Concurso público internacional de arquitetura. Centro Cultural Gabriela Mistral. Bases". In Cuatro concursos de arquitectura pública, edited by Dirección de Arquitectura/ Ministerio de Obras Públicas. Pp.107-112: http://www. arquitecturamop.cl/centrodocumental/Documents/4\%20 concursos_02.pdf [accessed 03/October/2014]

Errázuriz, Luis Hernán and Leiva, Sebastian (2012) El golpe estético. Dictadura militar en Chile (1973-1989). Ocholibro, Santiago.

Fernandez, Cristian (2010) Centro Cultural Gabriela Mistral/ Cristian Fernández Arquitectos/Lateral Arquitectura \& Diseño. http://www.plataformaarquitectura.cl/cl/02-52707/centrocultural-gabriela-mistral-cristian-fernandez-arquitectos-lateralarquitectura-diseno [accessed 09/September/2014].

Foucault, Michel (1997) "Of Other Spaces: Utopias and Heterotopias". In Rethinking Architecture: a Reader in Cultural Theory, edited by Leach, Neil. Routledge, London, pp. 350-356.

Gobierno de Chile (2013) La Moneda. Palacio de Gobierno de Chile. Universidad Finis Terrae, Santiago.

Hartog, François (2007) Régimenes de historicidad: presentismo y experiencia del tiempo. Universidad Iberoamericana, México DF.

Hite, Katherine (2003) "El monumento a Salvador Allende en el debate político chileno". In Monumentos, memoriales y marcas territoriales, edited by Jelin, Elizabeth and Langland, Victoria. Siglo XXI, Madrid and Buenos Aires, pp. 19-55.

Hobsbawm, Eric and Ranger, Terence (editors) (1983) The invention of tradition. Cambridge Univerity Press, Cambridge.

Huneeus, Carlos (2003) Un país dividido: la actualidad del pasado. Catalonia, Santiago.

Illañéz, Maria Angélica (2002) La batalla de la memoria. Planeta/ Ariel, Santiago.

Jelin, Elizabeth (2013) "Memoria y democracia: una relación incierta". Revista de Ciencia Politica de la Universidad de Chile, 51 (2): 129-144. http://www.revistapolitica.uchile.cl/index.php/ RP/article/viewPDFInterstitial/30162/31906 [accessed 09/September/2014] 
Jelin, Elizabeh and Langland Victoria (2003) Monumentos, memoriales y marcas territoriales. Siglo XXI, Madrid and Buenos Aires.

Lagos Escobar, Ricardo (2003) No hay mañana sin ayer. Propuesta del Presidente Lagos sobre Derechos Humanos. Gobierno de Chile, Santiago. http://bibliotecadigital.indh.cl/bitstream/handle/ 123456789/183/no-hay-manana.pdf?sequence $=1$ [accessed 08/ September/2014].

Lawner, Miguel (2008) "Viviendas dignas para hombres dignos". In Salvador Allende. Presencia en la ausencia, edited by Lawner, Miguel. LOM, Santiago, pp. 281-304.

Llano, Jose and Varas, Paulina (editors) (2010) 275 dias. Sitio, Tiempo, Contexto y Afecciones Especificas. Curatoría para el edificio Centro Cultural Gabriela Mistral. Santiago. http://issuu. com/jllano/docs/275 web final [Accessed 09/September/2014]

Logan, William and Reeves, Keir (editors) (2009) Places of Pain and Shame. Dealing with a Difficult Heritage. Routledge, New York.

Lopez, Loreto (2009) "De centros de detención a lugares de memoria". Archivo Londres 38. http://www.londres38.cl/1934/w3-article88243.html [accessed 08/September/2014].

MacDonald, Sharon (2009) Difficult Heritage: Negotiating the Nazi Past in Nuremberg and Beyond. Routledge, New York.

Montealegre, Jorge (2003) Frazadas del Estadio Nacional. LOM, Santiago.

Miguez, Antonio (2012) "Practicas genocidas en España. Discursos, lógicas y memoria 1936-1977". Historia Contemporánea, 45: 545-573. http://www.ehu.es/ojs/index.php/HC/article/view/ 7492/6672 [Accessde 03/October/2014].

Nora, Pierre (1984) "Entre mémoire et histoire. La problematique des lieux". In Les lieux de mémoire: La Republique (volume I), edited by Nora, Pierre. Gallimard, Paris, pp. XVIII-XLII.

Nora, Pierre (1992) "L'ère de la commémoration". Les lieux de mémoire : Les Frances (volume III), edited by Nora, Pierre. Gallimard, Paris, pp. 975-1012.

Observatorio de Derechos Humanos, Universidad Diego Portales (2013) Estadisticas causas de DDHH, Chile. http://www.icso. cl/observatorios/observatorio-derechos-humanos/cifras-causascase-statistics/ [Accessed 08/September/2014].
Ortiz, Carmen (editor) (2013) Lugares de represión, paisajes de la memoria. La cárcel de Carabanchel. Catarata, Madrid.

Parot, Carmen (2002) Estadio Nacional [Documentary] Chile, 111 minutes.

Piper, Isabel and Hevia, Evelyn (2012) Espacio y recuerdo. Archipiélago de memorias en Santiago de Chile. Ocholibros, Santiago.

Riegl, Alois (1987) El culto moderno a los monumentos. Carácter y orígenes. 1st edition 1903. Visor Distribuciones S.A., Madrid.

Rozas, Valentina (2013) "Tres maneras de explicar la presencia de graderías antiguas en un Estadio remodelado". Revista Bifurcaciones, 14:1-16. http://www.bifurcaciones.cl/2013/10/ graderias-antiguas-en-un-estadio-remodelado/ [Accessed 09/ September/2014].

Stern, Steve (2004) Remembering Pinochet's Chile. On the Eve of 1998 (Book I). Duke University Press, Durham.

Stern, Steve (2006) Battling for Hearts and Minds. Memory Struggles in Pinochet's Chile (Volume II). Duke University Press, Durham.

Todorov, Tzvetan (2013) "Los usos de la memoria, Memoria". Revista sobre cultura, democracia y derechos humanos, 10, May. http://idehpucp.pucp.edu.pe/wp-content/uploads/2012/09/ Todorov.pdf [accessed 09/October/2014]

Vinyes, Ricard (editor) (2004) Un futuro para el pasado. Proyecto de creación del Memorial Democrático. Centre d'Estudis sobre les epoques franquista i democrática (CEFID). http://www. londres38.cl/1934/articles-83853_recurso_1.pdf [accessed 09/ October/2013].

Violi, Patrizia (2011) "È successo propio qui. Gli ambienti come testimoni. Analisi del caso cileno". Lexia. Rivista di semiotica, 9 (10): 95-132.

Wilde, Alex (1999) "Irruptions of Memory: Expressive Politics in Chile's Transition to Democracy". Journal of Latin American Studies, 31 (2): 473-500.

Winn, Peter; Stern, Steve; Lorenz, Federico and Marchesi, Aldo (2014) No hay mañana sin ayer: batallas por la memoria histórica en el Cono Sur. Instituto de Estudios Peruanos, Lima. 